\title{
Morphological and elementary evaluation of wooden carbonaceous materials from activated carbon industry
}

\author{
Everson do Prado BANCZEK ${ }^{1 *}$, Aline Barbiere BRUGNERA ${ }^{1}$, André Luis CHRISTOFORO², \\ Gilmara de Oliveira MACHADO ${ }^{2}$ \\ ${ }^{1}$ Departamento de Química, Universidade Estadual do Centro-Oeste, Guarapuava, PR, Brasil. \\ ${ }^{2}$ Departamento de Engenharia Florestal, Universidade Estadual do Centro-Oeste, Guarapuava, PR, Brasil. \\ *E-mail: edopradobanczek@yahoo.com.br
}

Recebido em junho/2018; Aceito em outubro/2018.

\begin{abstract}
The worldwide concern of reducing greenhouse gases into the atmosphere combined with more stringent environmental laws has led to an increase in studies of renewable energy. This research aimed to characterize wood chips and activated charcoal by scanning electron microscopy (SEM) and energy dispersive spectroscopy (EDS). The chips came from an energy forest of Pinus elliottii and were burned in the furnace of a boiler for steam generation. This steam generated by the boiler in appropriate furnaces is used in the activation of wood charcoal from small regional producers. SEM showed an increase in the porosity of the charcoal with the activation process, and EDS analysis indicated both chips and charcoals, with and without activation, have no contaminants, such as heavy metals. This study revealed a low toxicity of lignocellulosic materials based on Pinus elliottii. The burning of wooden chips in the boiler as well as the activation process of wood charcoal did not present apparent environmental risks.
\end{abstract}

Keywords: forestry energy, carbonization, activated carbon, metals, porosity.

\section{Avaliação morfológica e elementar de materiais carbonáceos de madeira da indústria de carbono ativada}

\begin{abstract}
RESUMO: A preocupação mundial na redução dos gases de efeito estufa para a atmosfera, combinada com leis ambientais mais rigorosas, tem levado a um aumento dos estudos sobre a energia renovável. Esta pesquisa teve como objetivo caracterizar lascas de madeira e carvão ativado por microscopia eletrônica de varredura (MEV) e espectroscopia de energia dispersiva (EDS). Os cavacos são oriundos de uma floresta de Pinus elliottii voltada para fins energéticos e foram queimados em uma fornalha de uma caldeira de geração de vapor. Esse vapor gerado pela caldeira em fornalhas apropriadas é utilizado na ativação de carvão vegetal por pequenos produtores regionais. MEV indicou um aumento na porosidade do carvão vegetal com o processo de ativação, e a análise EDS indicou que tanto os cavacos quanto os carvões, com e sem ativação, não apresentaram contaminantes, como os metais pesados. Este estudo revelou uma baixa toxicidade dos materiais lignocelulósicos à base de Pinus elliottii. A queima de cavacos de madeira na caldeira e o processo de ativação de carvão vegetal não apresentaram riscos ambientais.
\end{abstract}

Palavras-chave: energia florestal, carbonização, carvão ativado, metais, porosidade.

\section{INTRODUCTION}

Many countries have tried to increase the share of renewable sources in their energy matrices, seeking to develop new modern technologies, which enable the increase of the mass production of food and industrialized products, while also reducing the emission of greenhouse gases. Forest biomass is an easily available resource in Brazil at competitive costs, which it has been a focus for several studies. The forest biomass presents potential for new energy generation and benefits for the reduction of greenhouse effect gases (MACHADO et al., 2013). But, to establish the mass production of activated carbon from biomass, it is important to secure the resources from the viewpoint of supply chain costs (XIA et al., 2012). For this, woody waste materials from reforestation and other agricultural waste materials emerge as an important way to supply this demand.

Low-cost and renewable agricultural wastes are efficiently being converted into activated carbon (YAHIA et al., 2015).
Activated carbons derived from agricultural wastes have been investigated as a replacement for expensive methods of removing heavy metals from wastewater (MOHAN; SINGH, 2002).

Researchers have developed alternatives for biomass from agricultural waste such as flax shives (MARSHALL et al., 2007), rice stalk (AI et al., 2013), rice straw (HU; HSIEH, 2014), orange peel (KÖSEOĞLU; AKMIL-BAŞAR, 2015), cotton stalk (NAHIL; WILLIAMS, 2012), cocoa shell (AHMAD et al., 2013), grape stalk (DEIANA et al., 2009), apple peel (HESAS et al., 2013), and tea fruit peel (GAO et al., 2013).

Another modern trend for biomass is related to the utilization of lignocellulosic materials and their wastes, such as tropical peat (KHADIRAN et al., 2015), bamboos (GONZÁLEZ et al., 2014), natural fibers (REED; WILLIAMS, 2004), and woods. The use of woods and their wastes as inputs (fuel) for biomass is an important and popular 
alternative for energy generation. Clear examples are given in the numerous studies based on the wood species Hevea brasiliensis (SRINIVASAKANNAN;ABU BAKAR, 2004), Ailanthus altissima (BANGASH; ALAM, 2009), Tamarindus indica (ACHARYA et al., 2009), Prosopis ruscifolia (NABARLATZ et al., 2012), Cunninghamia lanceolata (LIU; ZHAO, 2012), Neobalanocarpus heimii (FOO; HAMEED, 2012), Eucalyptus camaldulensis (HEIDARI et al., 2014), Populus euramevicana (ZHANG; ZHANG, 2014), and Caesalpinia coriana(HERNÁNDEZ et al., 2014), as well as other constituents and or wastes, e.g., Delonix regia pods (VARGAS et al., 2011), Albizia lebbeck seeds (AHMED; THEYDAN, 2014), Copernicia prunifera leaves and Acrocomia aculeata seeds (LACERDA et al., 2015).

Among the sources of forest biomass, wood is highlighted because of its potential use in natural form (firewood), even in processed products in solid form (charcoal) or liquid form (pyrolysis oils), and in the use of forestry waste (pruning debris and branches) or industrial products (briquettes and pellets). These aforementioned authors emphasize the possibility of exploration or planting, without exclusive reliance on fossil fuels, is another advantage of wood as an energy source. In this aspect, woods from human planted forests, especially those of rapid growth such as Pinus spp. and Eucalyptus spp. and their industrial wastes, emerge as cheaper alternatives to produce activated carbon on a large scale. Pine is widely used as charcoal, especially in Brazil, and sawmills produce large amounts of residues of pine lumber, characterizing this waste as a relevant raw material for activated carbon. On the other hand, Eucalyptus forests are almost completely used for cellulose and paper.

Boilers are industrial machines which use the burning of fuels such as biomass from firewood, wood chips, and sawdust to produce steam. In the activation process of wood charcoal, a carbon-rich material, the steam released by the boiler, under specific conditions, acts as an activating agent in special ovens (CUNHA et al., 1989).

Wood charcoal is a result of carbonization, a thermal process which raises the carbon content of wood from approximately $50 \%$ to $80 \%$ in charcoal. Carbonization is a slow pyrolysis process which occurs in the temperature range from 300 to $400{ }^{\circ} \mathrm{C}$, generating gases $\left(\mathrm{CO}, \mathrm{CO}_{2}, \mathrm{H}_{2}, \mathrm{CH}_{4}\right)$, as well as a liquid fraction rich in organic acids (pyroligneous acid) and a solid fraction (charcoal). Charcoal production in Brazil has significant economic importance, and is basically developed in two ways: traditional, which uses wood from native forests, usually harvested for the transformation of forest areas in agriculture; and modern, which uses wood from planted forests (KRONKA et al., 2005).

Activated charcoal is produced by wood carbonization and activation, as well as is also known through the nomenclature activated carbon. Ngernyen et al. (2006) state the activated carbon is a highly porous material which is widely used as an adsorbent for separation, purification and recovery processes. Kroschwitz; Howe-Grant (1992) indicates there are two processes for the preparation of activated carbons: physical and chemical.

Chemical activation is performed in a single step of combined carbonization and activation by using chemical activating agents - zinc chloride, potassium hydroxide, or phosphoric acid - at temperatures in the range from 400 to 800 ${ }^{\circ} \mathrm{C}$ (KROSCHWITZ; HOWE-GRANT, 1992). Physical activation involves the carbonization of a carbonaceous material in an inert atmosphere followed by the activation of the resulting char at higher temperatures from 800 to $1100{ }^{\circ} \mathrm{C}$ in the presence of activating agents, e.g., carbon dioxide, air, steam or a gas mixture (NGERNYEN et al., 2006).

Activated carbon has been used as all-purpose sorbent with extensive applications in the removal of organic and inorganic contaminants from solutions as well as in processes of gas purification (KIM et al., 2001). Activated carbons, with their high porosity, are extensively used in industrial purification and chemical recovery operations (TENG et al., 1998).

Analysis by Energy Dispersive Spectroscopy (EDS) is a very important tool associated with Scanning Electron Microscopy (SEM) for the characterization of metallic and semi-conductor materials because it allows the researchers to identify the elemental composition of samples in specific points of an image. In organic raw materials, EDS can identify the presence of heavy metals, which contributes to the evaluation of toxicity and of the possible environmental impact of the use of wood chips in the processes of combustion and of activated charcoal.

This study aimed to evaluate the surface morphology and the occurrence of heavy metals through SEM and EDS of Pinus elliottii chips used in the generation of thermal energy by a boiler and of the activated charcoal from the steam generated by this boiler.

\section{MATERIAL E METHODS}

Samples of wooden chips of Pinus elliottii, activated carbon, and waste from the activation process were collected. Wooden chips were used as the boiler fuel for steam generation, which was used in the activation of charcoal in the activation furnaces. The wood charcoal went through an initial process of sieving to separate finer materials (waste). After this stage, thicker material was utilized in the activation process. These samples were collected from the Brazilian company named Brascarbo Agroindustrial Ltd.

The morphological characterization was performed by scanning electron microscopy (SEM) using a 2011 Tescan, Czech Republic, Vegas 3 model microscope. Three samples of wood chips were analyzed as follows: boiler fuel, with image magnification of 500x; sample of finer material (waste) which had not been activated and represented the original charcoal, with image magnification of $1500 \mathrm{x}$; and activated carbon (final product) at $1500 x$.

The samples were fixed using a double-sided conductive tape on a Quorum Q150R display. After this tape fixation in the device, the samples were dispersed in powder over the conductive tape and the excess was removed, with a double repetition of this step. The samples were metallized with gold and analyzed by a sputtering coater of Quorum Technologies Ltd., (model Q150 R, Ashford, Kent, England).

\section{RESULTS}

A micrograph of the wood chip sample is shown in Figure 1a, and the EDS spectrum for this respective sample is given by the Figure 2. Micrographs obtained by SEM of waste charcoal, representing the original wood charcoal and the activated charcoal, are shown in Figures $1 \mathrm{~b}$ and $1 \mathrm{c}$, respectively. The samples were also evaluated with respect to elemental chemical composition (Figures 3 and 4).

The EDS spectra present the elemental composition of the materials. Thus, we observed many elements are present, which were measured as percentages (Table 1). 


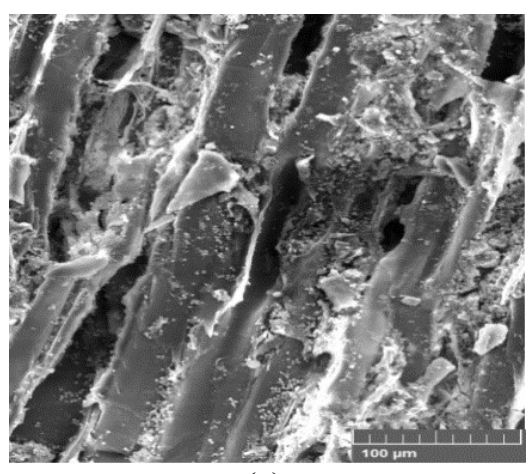

(a)

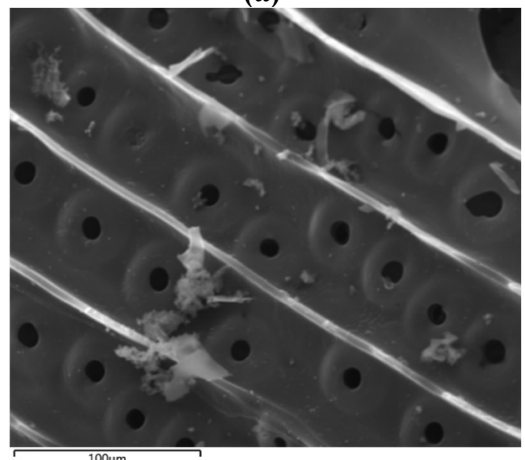

(b)

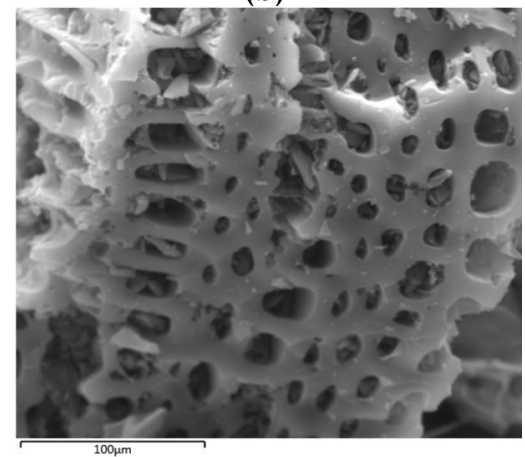

(c)

Figure 1. Micrographs (magnification of 1500x): (a) micrograph obtained by MEV for wood chip sample, (b) charcoal waste, and (c) charcoal after the activation process.

Figura 1. Micrografias (ampliação de 1500x): (a) micrografia via MEV para a amostra de lascas de madeira, (b) resíduos de carvão e (c) carvão depois do processo de ativação.

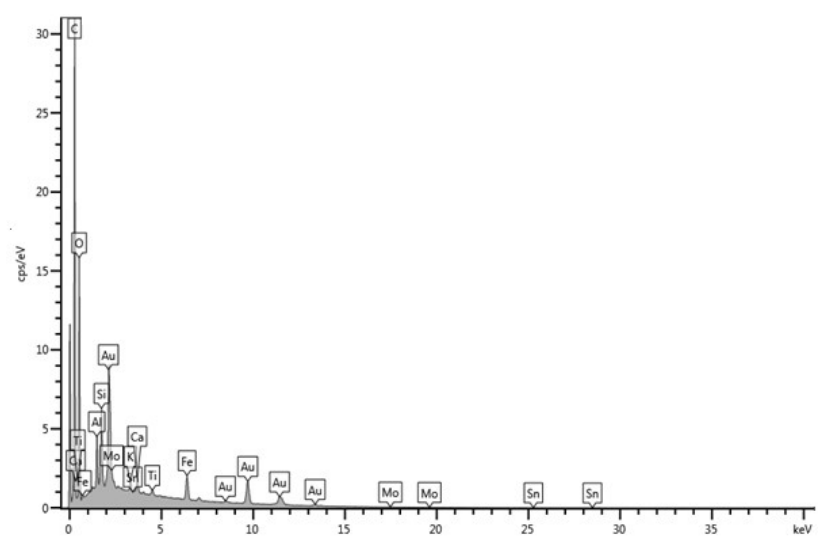

Figure 2 - EDS spectrum for wooden chip sample.

Figura 2 - Espectro EDS para a amostra de lascas de madeira.

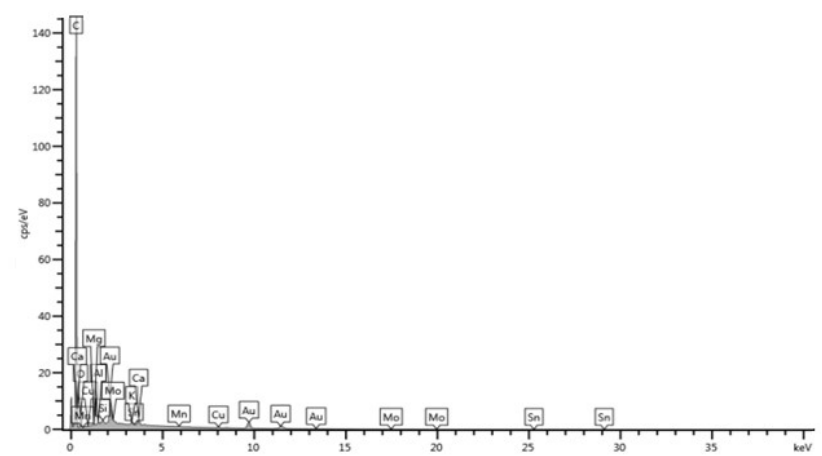

Figure 3 - EDS spectrum of wood charcoal waste before the activation process.

Figura 3 - Espectro EDS para o resíduo de carvão vegetal antes do processo de ativação.

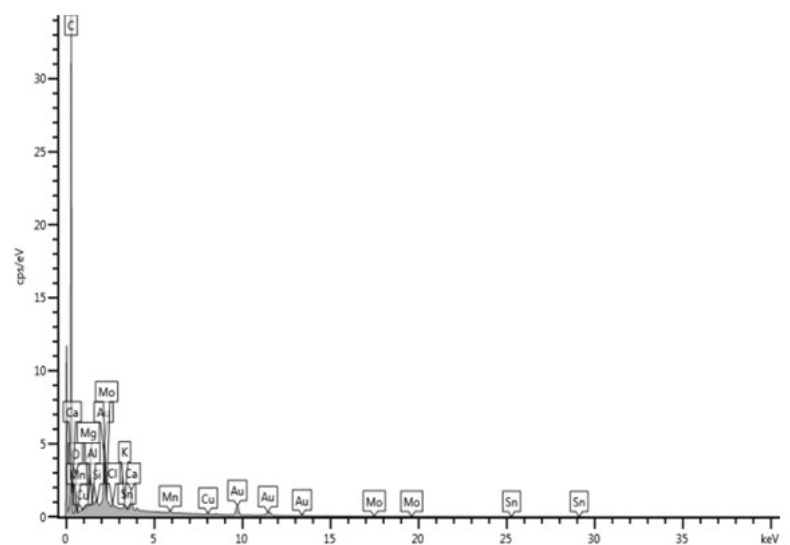

Figure 4 - EDS spectrum of wood charcoal waste after the activation process.

Figura 4 - Espectro EDS para o resíduo de carvão vegetal depois do processo de ativação.

Table 1. Elemental composition of wood chips and wood charcoals: non-activated and activated.

Tabela 1. Composição elementar de lascas de madeira e dos carvões de madeira: não ativado e ativado.

\begin{tabular}{cccc}
\hline \multirow{2}{*}{ Elements } & \multicolumn{3}{c}{ Samples (\%) } \\
\cline { 2 - 4 } & wood chips & $\begin{array}{c}\text { Non-activated } \\
\text { charcoal }\end{array}$ & $\begin{array}{c}\text { Activated } \\
\text { charcoal }\end{array}$ \\
\hline $\mathrm{O}$ & 66.04 & 39.05 & 54.33 \\
$\mathrm{Mg}$ & 0.00 & 0.59 & 1.54 \\
$\mathrm{Al}$ & 3.68 & 1.23 & 0.79 \\
$\mathrm{Si}$ & 4.35 & 1.46 & 0.34 \\
$\mathrm{Cl}$ & 0.00 & - & 0.96 \\
$\mathrm{~K}$ & 0.7 & 2.11 & 2.37 \\
$\mathrm{Ca}$ & 0.94 & 4.86 & 5.50 \\
$\mathrm{Mn}$ & 0.00 & 0.71 & 0.79 \\
$\mathrm{Cu}$ & 0.00 & 1.25 & 0.47 \\
$\mathrm{Mo}$ & 7.77 & 7.38 & 4.69 \\
$\mathrm{Sn}$ & 0.00 & 0.00 & 0.17 \\
\hline
\end{tabular}

O: oxygen; $\mathrm{Mg}$ : magnesium; $\mathrm{Al}$ : aluminium; $\mathrm{Si}$ : silicon; $\mathrm{Cl}$ : chlorine; $\mathrm{K}$ : potassium; $\mathrm{Ca}$ : calcium; $\mathrm{Mn}$ : manganese; $\mathrm{Cu}$ : copper; Mo: molybdenum; $\mathrm{Sn}$ : tin.

\section{DISCUSSION}

Wooden chip is a material with relative porosity and a heterogeneous surface. These chips were stored in a hangar at Brascarbo Agroindustrial Ltd., near the boiler and the furnace, ensuring drying before wood chip burning. While combustion is a heterogeneous chemical reaction between the fuel and oxygen, the porosity of chips will favor gas exchange and increase the contact surface between reactants, favoring a clean burning. 
With the EDS spectrum is possible to detect the quantities of metals present in the chip samples, such as oxygen, $66.04 \%$ $(\mathrm{O})$; aluminum, 3.68\% (Al); silicon, $4.35 \%$ (Si); calcium, $0.94 \%(\mathrm{Ca})$; potassium, $0.70 \%(\mathrm{~K})$; titanium, 0.45\% (Ti); molybdenum, 7.77\% (Mo); iron, 3.05\% (Fe); tin, 0.00\% (Sn); and gold, $18.03 \%(\mathrm{Au})$ from sample treatment. Thereby, by EDS analysis is observed there is no presence of toxic heavy metals (e.g., cadmium, mercury, lead, and arsenic), characterizing the chip sample as very low toxicity material (Figure 4).

The activation was accomplished with steam generated by the boiler in activation furnaces at a temperature ranging from 800 to $1100{ }^{\circ} \mathrm{C}$. Through a comparison between Figures $1 \mathrm{~b}$ and $1 \mathrm{c}$, we can perceive the activation promotes an increase in the material porosity, especially the internal porosity. This increasing porosity was also present in the study of BANGASH; ALAM (2009) for activated carbon of Ailanthus altissima wood species at $800{ }^{\circ} \mathrm{C}$.

Differences in pore size can also be observed, where this different porosity is classified according to the size of macro-, meso-, and micro-porosity. The increase in porosity also causes an increase in the internal surface area, where the adsorption occurs; in larger surfaces, the adsorption efficiency will be greater. The size and shape of pores can also influence the selectivity of adsorption by the molecular sieve effect. The porous structure alteration is important for the development of the surface area of activated charcoal, where most of its superficial characteristic is attributed to the micropores, with some contribution of mesopores (LU et al., 1995). Activation increased the porosity of the charcoal residue, which suggests an increase in the adsorbent characteristics.

According to the data obtained by EDS, we verified there was an increase in the amounts of oxygen $(\mathrm{O})$, magnesium $(\mathrm{Mg})$, tin $(\mathrm{Sn})$, potassium $(\mathrm{K})$, manganese $(\mathrm{Mn})$, calcium $(\mathrm{Ca})$, and chlorine $(\mathrm{C})$, as well as a decrease in the contents of aluminum $(\mathrm{Al})$, silicon $(\mathrm{Si})$, copper $(\mathrm{Cu})$, and molybdenum (Mo), for the non-activated sample compared with the activated carbon sample. The decrease in the amount of metallic elements shows that the process of activation of the charcoal promotes the leaching of these elements from the active sites of the charcoal. This behavior may be interesting if we consider that, after activation, if this charcoal is used to remove metals from residual waters, it can be reused after reactivation, since the adsorption of the metals is not irreversible.

However, as detected in the elemental composition of wood chips, we observed the non-occurrence of toxic heavy metals, which, if present, could make the use of charcoal for both activation and for the application of activated carbon unviable because toxic metals promote environmental pollution and can accumulate, which is very dangerous for living beings.

\section{CONCLUSIONS}

The characterization by scanning electron microscopy (SEM) showed an increase in the porosity of the wood charcoal after the activation process.

The activation process increased the internal area of the charcoal, making the material more efficient when used for adsorption.

Through the analysis of energy dispersive spectroscopy (EDS) was revealed wood chips, charcoal and activated carbon had no toxic heavy metals in their compositions, which enables the use of Pine charcoal, both for activation and for applications of activated charcoal.

\section{REFERENCES}

ACHARYA, J.; SAHU, J. N.; MOHANTY, C. R.; MEIKAP, B. C. Removal of lead (II) from wastewater by activated carbon developed from Tamarind wood by zinc chloride activation. Chemical Engineering Journal, Lausanne, v. 149, n. 1-3, p. 249-262, 2009. DOI: https://dx.doi.org/10.1016/j.cej.2008.10.029

AHMAD, F.; DAUD, W. M. A. W.; AHMAD, M. A.; RADZI, R.; AZMI, A. A. The effects of $\mathrm{CO}_{2}$ activation, on porosity and surface functional groups of cocoa (Theobroma cacao) - shell based activated carbon. Journal of Environmental Chemical Engineering, v. 1, n. 3, p. 378-388, 2013. DOI: https://dx.doi.org/10.1016/j.jece.2013.06.004

AHMED, M.J., THEYDAN, S.K. Optimization of microwave preparation conditions for activated carbon from Albizia lebbeck seed pods for methylene blue dye adsorption. Journal of Analytical and Applied Pyrolysis, v. 105, p. 199-208, 2014.2 DOI: https://dx.doi.org/10.1016/j.jaap.2013.11.005

AI, N.; ZENG, G.; ZHOU, H.; HE, Y. Co-production of activated carbon and bio-oil from agricultural residues by molten salt pyrolysis. BioResources, Raleigh, v. 8, n. 2, p. 1551-1562, 2013.

BANGASH, F. K.; ALAM, S. Adsorption of acid blue 1 on activated carbon produced from the wood of Ailanthus altissima. Brazilian Journal of Chemical Engineering, São Paulo, v. 26, n. 2, p. 275-285, 2009. DOI: http://dx.doi.org/10.1590/S0104-66322009000200005

CUNHA, M. P. S. C., PONTES, C. L. F., A., C. I., CABRAL, M. T. F. D., NETO, Z. B., \& BARBOSA, A. P. Estudo químico de 55 espécies lenhosas para geração de energia em caldeiras. Encontro Brasileiro Em Madeiras e em Estruturas de Madeira, 3., 1989, São Carlos. Anais...São Carlos: 1989. v. 2. p. 93- 121.

DEIANA, A. C.; SARDELLA, M. F.; SILVA, H.; AMAYA, A.; TANCREDI, N. Use of grape stalk, a waste of the viticulture industry, to obtain activated carbon. Journal of Hazardous Materials, Amsterdam, v. 172, n. 1, p. 13-19, 2009.

DOI: https://dx.doi.org/10.1016/j.jhazmat.2009.06.095

FOO, K. Y.; HAMEED, B. H. Mesoporous activated carbon from wood sawdust by $\mathrm{K}_{2} \mathrm{CO}_{3}$ activation using microwave heating. Bioresource Technology, Essex, v. 111, p. 425432, 2012.2 DOI: https://dx.doi.org/10.1016/j.biortech.2012.01.141

GAO, J.; KONG, D.; WANG, Y.; WU, J.; SUN, S.; XU, P. Production of mesoporous activated carbon from tea fruit peel residues and its evaluation of methylene blue removal from aqueous solutions. BioResources, Raleigh, v. 8, n. 2, p. 2145-2160, 2013.

GONZÁLEZ, P. G.; HERNÁNDEZ-QUIROZ, T.; GARCÍAGONZÁLEZ, L. The use of experimental design and response surface methodologies for the synthesis of chemically activated carbons produced from bamboo. Fuel Processing Technology, Amsterdam, v.127, p.133-139, 2014. https://dx.doi.org/10.1016/j.fuproc.2014.05.035

DOI:

HEIDARI, A.; YOUNESI, H.; RASHIDI, A.; GHOREYSHI, A. Adsorptive removal of $\mathrm{CO}_{2}$ on highly microporous activated carbons prepared from Eucalyptus camaldulensis 
wood: effect of chemical activation. Journal of Taiwan Institute of Chemical Engineers, v. 45, n. 2, p. 579-588, 2014. DOI: https://dx.doi.org/10.1016/j.jtice.2013.06.007

HERNÁNDEZ, A. M.; LABADY, M.; LAINE, J. Granular activated carbon from wood originated from tropical virgin forest. Open Journal of Forestry, v. 4, n. 3, p. 208-211, 2014. DOI: http://dx.doi.org/10.4236/ojf.2014.43027

HESAS, R. H.; ARAMI-NIYA, A.; DAUD, W. M. A. W.; SAHU, J. N. Preparation and characterization of activated carbon from apple waste by microwave-assisted phosphoric acid activation: application in methylene blue adsorption. BioResources, Raleigh, v. 8, n. 2, p. 29502966, 2013.

KROSCHWITZ, J. I.; HOWE-GRANT, M. Encyclopedia of chemical technology. 4. ed.New York, NJ: John Wiley \& Sons, 1992. $1018 \mathrm{p}$.

HU, S.; HSIEH, Y. Preparation of activated carbon and silica particles from rice straw. ACS Sustainable Chemistry \& Engineering, Austin, v. 2, n. 4, p. 726-734, 2014. DOI: https://dx.doi.org/10.1021/sc5000539

KHADIRAN, T.; HUSSEIN, M. Z.; ZAINAL, Z.; RUSLI, R. Textural and chemical properties of activated carbon prepared from tropical peat soil by chemical activation method. BioResources, Raleigh, v. 10, n. 1, p. 986-1007, 2015.

KIM, S. H.; BIDKAR, A.; NGO, H. H.; VIGNESWARAN, S.; MOON, H. Adsorption and mass transfer characteristics of metsulfuron-methyl on activated carbon. Korean Journal of Chemical Engineering, Seoul, v. 18, n. 2, p. 163-169, 2001. DOI: https://dx.doi.org/10.1007/BF02698454

KÖSEOĞLU, E; AKMIL-BAŞAR, C. Preparation, structural evaluation and adsorptive properties of activated carbon from agricultural waste biomass. Advanced Powder Technology, v. 26, n. 3, p. 811-818, 2015. DOI: https://dx.doi.org/10.1016/j.apt.2015.02.006

KRONKA, F. J. N.; BERTOLANI, F.; PONCE, R. H. A Cultura do Pinus no Brasil. São Paulo: SBS/Páginas e Letras, 2005. $156 \mathrm{p}$.

LACERDA, V. S.; LÓPEZ-SOTELO, J. B.; CORREAGUIMARÃES, A.; HERNÁNDEZ-NAVARRO, S.; SÁNCHEZ-BÁSCONES, M.; NAVAS-GRACIA, L. M.; MARTÍN-RAMOS, P.; MARTÍN-GIL, J. Rhodamine B removal with activated carbons obtained from lignocellulosic waste. Journal of Environmental Management, London, v. 155, n. 2015, p.67-76, 2015. DOI: https://doi.org/10.1016/j.jenvman.2015.03.007

LIU, W.; ZHAO, G. Effect of temperature and time on microstructure and surface functional groups of activated carbon fibers prepared from liquefied wood. BioResources, Raleigh, v. 7, n. 4, p. 5552-5567, 2012.

LU, G.Q.; LOW, J.C.F.; LIU, C.Y.; LUA, A.C. Surface-area development of sewagesludge during pyrolysis. Fuel, London, v. 74, n. 3, p. 344-348, 1995. DOI: https://dx.doi.org/10.1016/0016-2361(95)93465-P

MACHADO, G. O.; COOKSON, L.; CHRISTOFORO, A. L.; POLITO, W. L.; SILVA, M. R.; CALIL JUNIOR, C.; LAHR, F. A. R. Wood preservation based on neem oil: evaluation of fungicidal and termiticidae effectiveness. Forest Products Journal, Madison, v. 63, p. 202-206, 2013. DOI: https://dx.doi.org/10.13073/FPJ-D-13-00050

MARSHALL, W. E.; WARTELLE, L. H.; AKIN, D. E. Flax shive as a source of activated carbon for metals remediation. BioResources, Raleigh, v. 2, n. 1, p. 82-90, 2007.

MOHAN, D.; SINGH, K. P. Single- and multi-component adsorption of cadmium and zinc using activated carbon derived from bagasse-an agricultural waste. Water Research, New York, v. 36, n. 9, p. 2304-2318, 2002. DOI: https://dx.doi.org/10.1016/S0043-1354(01)00447-X

NABARLATZ, D.; DE CELIS, J.; BONELLI, P.; CUKIERMAN, A. L. Batch and dynamic sorption of Ni (II) ions by activated carbon based on a native lignocellulosic precursor. Journal of Environmental Management, London, v. 97, n. 2012, p. 109-115, 2012. DOI: https://dx.doi.org/10.1016/j.jenvman.2011.11.008

NAHIL, M. A.; WILLIAMS, P. T. Pore characteristics of activated carbons from the phosphoric acid chemical activation of cotton stalks. Biomass \& Bioenergy, Oxford, v.37, p.142-149, 2012. DOI: https://dx.doi.org/10.1016/j.biombioe.2011.12.019

NGERNYEN, Y.; TANGSATHITKULCHAI, C.; TANGSATHITKULCHAI, M. Porous properties of activated carbon produced from Eucalyptus and wattle wood by carbon dioxide activation. Korean Journal of Chemical Engineering, Seoul, v. 23, n. 6, p.10461054,2006. DOI: https://dx.doi.org/10.1007/s11814-0060028-9

REED, A. R.; WILLIAMS, P. T. Thermal processing of biomass natural fibre wastes by pyrolysis. International Journal of Energy Research, Chichester, v. 28, n. 2, p. 131-145, 2004. DOI: https://dx.doi.org/10.1002/er.956

SRINIVASAKANNAN, C.; ABU BAKAR, M. Z. Production of activated carbon from rubber wood sawdust. Biomass \& Bioenergy, Oxford, v. 27, n. 1, p .89-96, 2004. DOI: https://dx.doi.org/10.1016/j.biombioe.2003.11.002

TENG, H.; YEH, T.-S.; HSU, L.-Y. Preparation of activated carbon from bituminous coal with phosphoric acid activation. Carbon, Elmsford, v. 36, n. 9, p. 1387-1395, 1998. DOI: https://dx.doi.org/10.1016/S00086223(98)00127-4

VARGAS, A. M. M.; CAZETTA, A. L.; GARCIA, C. A.; MORAES, J. C. G.; NOGAMI, E. M.; LENZI, E.; COSTA, W. F.; ALMEIDA, V. C. Preparation and characterization of activated carbon from a new raw lignocellulosic material: flamboyant (Delonix regia) pods. Journal of Environmental Management, London, v. 92, n. 1, p. 178184, 2011. DOI: https://dx.doi.org/10.1016/j.jenvman.2010.09.013

XIA, Y.; MASSE, D. I.; MCALLISTER, T. A.; BEAULIEU, C.; UNGERFELD, E. Anaerobic digestion of chicken feather with swine manure or slaughterhouse sludge for biogas production. Waste Management, Elmsford, v. 32, n.2012, p.404-409, 2012. DOI: https://dx.doi.org/10.1016/j.wasman.2011.10.024

YAHIA, M. A.; AL-QODAH, Z.; NGAH, C. W. Z. Agricultural bio-waste materials as potential sustainable precursors used for activated carbon production: a review. Renewable \& Sustainable Energy Review, v. 46, p. 218235, 2015.2 DOI: https://dx.doi.org/10.1016/j.rser.2015.02.051

ZHANG, J.; ZHANG, W. Preparation and characteristics of activated carbon from wood bark and its use for adsorption of $\mathrm{Cu}$ (II). Medžiagotyra, Kaunas, v. 20, n. 4, p. 474-478, 2014. DOI: http://dx.doi.org/10.5755/j01.ms.20.4.6400 